\title{
HISTÓRIA DA PENA DE MORTE NO BRASIL: ASPECTOS GERAIS
}

\section{HISTORY OF THE DEATH PENALTY IN BRAZIL: GENERAL ASPECTS}

ERIC ALLEN BUENO

Acadêmico do curso de Direito - Faculdade do Litoral Paranaense - ISEPE. Guaratuba -PR. E-mail: erichistoria@gmail.com.

\section{LUCIANO RAITER}

Professor Orientador - Faculdade do Litoral Paranaense - ISEPE. Guaratuba - PR. E-mail: direito@isepe.edu.br

\section{RESUMO}

Com a eleição de Jair Bolsonaro à Presidência da República houve uma virada política à direita no Brasil, fortalecendo discursos autoritários, armamentistas e penalistas. Neste contexto se retomam discussões de longa data como a volta da Pena de Morte, como pena punitiva, deixando assim de ser uma exceção para os casos de guerra declarada como prevê a Constituição Federal de 1988. Este trabalho busca compreender o porquê desta penalidade ter sido abolida no passado, com este objetivo, analisou-se a legislação, os argumentos e fatos históricos que levaram o Estado a suspender a pena capital. Ao longo da pesquisa, traçou-se a historicidade da penalidade, abordando as discussões do Senado que, desde 1851 reivindicavam a abolição da escravidão e o fim da pena de morte. Fatos concretizados com a Lei Áurea de 1888 e com o Código Penal de 1890, o primeiro da República. Entretanto, mais de quarenta anos depois, a pena de morte volta a vigorar na Ditadura do Estado Novo de Vargas através da Emenda Constitucional nำ de 1938, acrescida a 
Personalidade Acadêmica Homenageada:

Augustus B. Cochran III (Agnes Scott College)

Constituição de 1937. A motivação da volta da pena máxima não ocorre por interesse social mas sim pela tentativa de golpe contra Getúlio Vargas realizada por alguns Integralistas. Entretanto, para além vingança do presidente, a pena de morte foi acrescida ao projeto do Código Penal de 1940, de Alcântra Machado, (o que evidência uma clara tendência punitivista) mas que sofre muitas alterações pelo Poder Legislativo que desvirtuou o texto original e configurou o atual Código. Portanto, no atual contexto social em que cresce a visão autoritária e se clama por penas mais duras, esta pesquisa se justifica pela necessidade de se compreender a real efetividade desta ação repressiva com base em nossa própria experiência histórica. Para a análise das fontes foram utilizados como referencial teórico metodológico a análise do discurso com Cesare Beccaria e Michel de Foucalt.

PALAVRAS-CHAVE: Direito Penal; Pena de Morte; Punitivismo.

\section{REFERÊNCIAS}

BECCARIA, Cesare Bonesana. Dos delitos e das penas. São Paulo: Martin Claret, 2014.

FOUCALT, Michel. A ordem do Discurso. 15ª̣ed. São Paulo: Edições Loyola, 1997. . Vigiar e Punir: nascimento da prisão. 34ªed. Ed. Petrópolis, RJ: Vozes, 2007.

GRINBERG, Keila. Processos criminais. A história nos porões dos arquivos judiciários. In PINSKY, Carla Bassanezi. O historiador e suas fontes. São Paulo: Contexto, 2011. p.119-139.

SANTIAGO, Nestor Eduardo e XEREZ, Rafael Marcílio. As razões epistemológicas para a inadmissibilidade da pena de morte: um ensaio a partir do filme "A vida de David Gale". Revista Jurídica - UNICURITIBA. Vol. 03, no48, Curitiba, 2017. pp. 388-410. 